\title{
Evaluation of sensory and chemical parameters of fermented sausages
}

\author{
Ivana Brankovic Lazic ${ }^{1 *}$, Jelena Jovanovic ${ }^{1}$,Stefan Simunovic ${ }^{l}$, Mladen Raseta ${ }^{1}$, Dejana Trbovic ${ }^{l}$, \\ Tatjana Baltic ${ }^{l}$, Jelena Ciric ${ }^{l}$
}

A b s t r a c t: Meat preservation became essential for transportation of meat for long distances without spoilage of texture, colour and nutritional value after the development and rapid growth of supermarkets. The most ancient methods of preserving meat are drying and fermentation of meat products. Fermented sausage is mostly industrially produced, although not standardized, but it is acceptable to the majority of the population. In this study, the sensory proprieties and chemical characteristics of kulen, a type of dry fermented sausage, were examined. Two groups of kulen sausages had differing percentages of pork meat and sweet and cayenne pepper, while the amount of solid fat tissue and other ingredients added at manufacturing were the same. The results obtained show the ingredients used might have an influence on kulen's sensory properties, in this case especially on odour, taste, cross-section colour and overall acceptability average scores. Chemical analyses showed that kulen group 1 had a higher protein content (24.52\%) than kulen group 2, which contained $23.00 \%$ meat protein, while the content of collagen in the meat protein was $7.02 \%$ (group 1 ) and $9.16 \%$ (group 2). Moisture in all these kulen sausages was less than 35\%, while the values of other parameters were similar between the two kulen groups. Therefore, the raw materials and the other ingredients used in the technological production of kulen fermented sausage can influence the final product quality.

Keywords: fermented sausage, sensory analysis, chemical analysis.

\section{Introduction}

Meat contains protein of high biological value and important micronutrients needed for good health throughout life. It also contains a range of fats, including essential omega-3 polyunsaturated fat (William, 2007). Meat preservation became essential for transportation of meat for long distances without spoilage of texture, colour and nutritional value after the development and rapid growth of supermarkets (Nytches et al., 2008). The most ancient methods of preserving meat are drying and fermentation of meat products. There are many historical accounts about the production and consumption of sausages in ancient civilizations, going back thousands of years.

However, there is no specific date for when sausage was first produced, because this dates from the period before written history (Savic, 1985). During the Middle Ages, great migrations led to the mixing of different cultures and customs, and therefore, knowledge of food conservation was transmitted worldwide more rapidly. After the Second World
War, development and modernization of product technology and equipment for fermented meat products continued (Babic and Babic, 2000). This kind of product has a specific microbiota that is typical of the region or area where they are produced. Naturally present or added lactic acid bacteria in fermented sausage produce acid, which has a positive effect on safety, sensory characteristics and shelf life of sausages (Comi et al., 2005; Petäjä-Kanninen and Puolanne, 2007; Zukál and Incze, 2010).

Fermented sausages are high-quality products. Traditionally, fermented sausages were considered healthy and safe foods. More recently, eating fermented sausages has been associated with health hazards caused by the high contents of saturated fats and $\mathrm{NaCl}$, the presence of nitrite and degradation products such as nitrosamines, and use of smoking that can lead to toxic compounds such as polycyclic aromatic hydrocarbons in the products. Hazards can also be both of direct microbiological nature, the sausages potentially being contaminated with foodborne pathogens, and of indirect microbiological nature by the metabolic activity of

${ }^{1}$ Institute of Meat Hygiene and Technology, Kacanskog 13, 11000 Belgrade, Republic of Serbia.

*Corresponding author: Brankovic Lazic Ivana ivana.brankovic@inmes.rs 
microorganisms causing the presence of biogenic amines and mycotoxins. The organoleptic and other properties of fermented sausages depend not only upon the products of bacterial fermentation of sugar, but are also strongly influenced by biochemical and physical changes occurring during the long drying or ageing process. The use of starter cultures for this category of raw sausages is less successful than for the semidry varieties. The lengths of production, either with or without smoking, and the drying period depend upon a multiplicity of factors, such as diameter and physical properties of casings, sausage formulation, choice and methods of preparing meat, drying conditions etc., but overall processing time can require up to 90 days. The final $\mathrm{pH}$ of dry sausages is usually slightly higher (5.0-5.5) than that of semidry sausages, and it increases during the second part of this long ageing process. Dry sausages are made from selected, mainly coarsely chopped, meat (some Italian salamis, some types of sudzuk); often they are moderately chopped (the majority of small-diameter dry sausages), and very occasionally they are finely chopped. They are cut in thin slices, their water content is $<35 \%$, but normally is $<30 \%$. Most varieties of dry sausage undergo cold smoking $\left(12\right.$ to $\left.18^{\circ} \mathrm{C}\right)$ but sometimes not; in some countries they are often heavily spiced with red pepper or garlic or sometimes are heavily smoked and strongly salted. In principle, they are processed by long, continuous air-drying, sometimes after a comparatively short period of smoking. The formulation, degree of grinding, level of fermentation, smoking intensity, temperature of ageing and type and size of casing as well as other factors determine the properties of the final product. Dry sausages are stuffed into natural or artificial casings of different diameters. Dry sausages are usually sold as moderately dry (about 30\% weight loss) and dry sausages (about $40 \%$ weight loss) (FAO, 2013).

There is a difference in fermented sausage technology between the United States and the European countries. US methods rely on rapid acid production (lowering the $\mathrm{pH}$ ) through a fast fermentation in order to stabilize the sausage against spoilage bacteria. Fast acting starter cultures such as Lactobacillus plantarum and Pediococcus acidilactici are used at high temperatures up to $40^{\circ} \mathrm{C}$. As a result, $\mathrm{pH}$ drops to 4.6 , the sausage is stable but the flavour suffers and the product is sour and tangy. In European countries, the temperatures of $22-26^{\circ} \mathrm{C}$ are used and the drying, instead of the acidity $(\mathrm{pH})$ is the main hurdle against spoilage bacteria; this favours better flavour development. The final acidity of a traditionally-made salami is low (high $\mathrm{pH}$ ) and there is no sour taste. There are different types of fermented sausages in hosts retail market such as kulen, winter salami, Srem sausage, sudzuk and tea sausage, but other types of related products also exist. In Serbia, this type of sausage is mostly industrially produced, which means the quality of this product is not standardised, but it is acceptable for the majority of the population because it is characterised by an attractive appearance, good grinding ability and pleasant aroma. Today, the national market offers dry fermented sausages with similar sensory properties (Petrohilou and Rantsios, 2005; Veskovic Moracanin et al., 2011)

According to Serbian regulation on the quality of ground meat, meat preparations and meat products (Serbia, 2015; 2017), fermented sausage can legally contain category 1 or 2 domestic pork, beef or equine meat, category 1 poultry meat or game meat, solid fat tissue, and additives. These ingredients are mixed, and after filling into casings, the sausages are preserved by drying and fermentation, with or without smoking. The drying process is carried out at a low temperature, and only then does sausage get its characteristic, spicy aroma, solid consistency and extended shelf life during the ripening process (Vukovic, 2012). Additives for fermented sausages, according to Serbian regulations, can be salt, curing salt, spices, spice extracts, sugars, additives, starter culture and beverages (wine and others). Fermented dry sausages must contain less than $35 \%$ water.

The aim of this paper was to point out the existence of differences in the sensory and chemical parameters of kulen, a dry fermented sausage, produced using two different recipes. These recipes differ in the quality of raw pork meat and the amount of added ingredients.

\section{Materials and Methods}

Fermented dry kulen sausage was produced according to two recipes, which differed in the category and quality pork meat and the amount of some added ingredients. Technological production processes were the same for both sausage groups. Kulen group 1 sausage included slightly better quality raw pork meat than the kulen group 2 . The other differences between those two groups were in their contents of sweet and cayenne pepper. Table 1 shows the percentage distribution of the ingredients used to manufacture the two groups of kulen.

The technological processing of the sausages took place under industrial conditions. The raw 
Table 1. The percentage distribution (\%) of ingredients used to produce two groups of kulen dry, fermented sausage

\begin{tabular}{lcc}
\hline Raw material & Group 1 kulen percentage (\%) & Group 2 kulen percentage (\%) \\
\hline Pork meat category 1 & 60 & 55 \\
Pork meat category 2 & 10.9 & 15.9 \\
Solid fat tissue & 25 & 25 \\
Nitrite salt & 2.5 & 2.5 \\
RADAferm & 0.05 & 0.05 \\
Dextrose & 0.2 & 0.2 \\
Ascorbic acid & 0.05 & 0.05 \\
Sweet pepper (oleoresin) & 0.7 & 0.8 \\
Cayenne pepper (oleoresin) & 0.3 & 0.2 \\
Garlic & 0.3 & 0.3 \\
\hline
\end{tabular}

materials, pork meat $\left(-4.3^{\circ} \mathrm{C}\right)$ and solid fat tissue $\left(-5.2^{\circ} \mathrm{C}\right)$ were minced in a cutter $(\mathrm{CFS}$ master). After that, other ingredients were added, while starter culture was added at the end of the process. The homogenization was carried out until an $8 \mathrm{~mm}$ granulation mosaic was obtained. Mixed sausage meats were stuffed using a vacuum filler into collagen casings, diameter 255 . Sausages were then hung on horizontal bars of drying racks and left in the anteroom of the automatic air conditioning chamber for about 4 to $6 \mathrm{~h}$. This procedure was used to optimize the process of fermentation/ripening, as the temperature of the filling needs to be raised as near as possible to the optimal temperature (recommendation: to achieve at least $18-19^{\circ} \mathrm{C}$, and ideally, $\left.22-24^{\circ} \mathrm{C}\right)$ before the fermentation process starts (Brankovic et al., 2019). This ensures optimal conditions for the metabolism of starter cultures (Brankovic et al., 2019). The production process (fermentation/drying and smoking, ripening) was a combination of automatic air conditioning chamber and traditional smoke chamber. This process lasted for 26 days.

Table 2. Numerical descriptive scale for the assessment of sensory properties

\begin{tabular}{cl}
\hline Number rating & Descriptive rating \\
\hline 5 & extremely acceptable \\
4 & very acceptable \\
3 & acceptable \\
2 & at the margin of acceptability \\
1 & unacceptable \\
\hline
\end{tabular}

\section{Laboratory analyses}

After production, the sausages were analysed in sensory and chemical laboratories accredited according to SRPS ISO/IEC 17025:2005.

\section{Sensory analyses}

Sensory properties of sausages (appearance, surface colour, cross-section colour, cross-section, odour, taste, consistency, salinity, seasoning, overall acceptability) were assessed using a quantitative-descriptive test (SRPS ISO, 2001b), with a grading scale from one to five $(1=$ unacceptable, $5=\mathrm{ex}-$ tremely acceptable) (Table 2). A five-person trained panel was assembled in order to evaluate the sensory properties. Panellists were previously tested for detection and recognition of various tastes (SRPS ISO, 2001a) and odours (SRPS ISO, 2002b). Sensory property results were the median value given by the five panellists.

\section{Chemical analyses}

After sensory evaluation, samples from each sausage were taken for chemical composition analysis. Total fat content (SRPS ISO, 1998b), $\mathrm{NaCl}$ (SRPS ISO, 1999) hydroxyproline content (SRPS ISO, 2002), moisture content (SRPS ISO, 1998a) and pH (SRPS ISO, 2004) were determined using standard reference methods. Nitrogen content was determined by an in-house method, the Kjeldahl method, and protein content was determined by multiplying the nitrogen content by 6.25 (Kjeltec Auto 1030 
Analyzer, Tecator, Sweden), while the $\mathrm{NaCl}$ content was determined by SRPS ISO, 1999.

\section{Statistical analysis}

The statistical analysis was performed using the GraphPad Prism version 7.00 software. The results were expressed as mean value and standard deviation and were subjected to analysis of variance (one-way ANOVA). The parameters were analysed using the Student's t-test at the probability of 0.05 . Pearson's correlation analysis was applied to examine the relationship between chemical characteristics and sensory properties of the two groups of kulen fermented sausages.

\section{Results and Discussion}

\section{Sensory Properties}

Two variants of kulen with slightly different categories of pork meat and different contents of sweet and cayenne pepper were prepared. The results of sensory analyses by professionally trained assessors are presented in Figure 1.

The obtained results showed the average scores for all tested sensory properties were similar between these two sausage groups. A higher rating was given to the group 2 kulen, which contained a slightly higher amount of category 2 pork meat. Also, this group of sausages contained a slightly higher percentage of red sweet pepper (oleoresin), but less cayenne pepper (oleoresin). Higher scores reflected the better odour, taste and consistency of group 2 kulen. Differences in amounts of sweet and cayenne pepper between these two groups of sausages affected scores for seasoning and overall acceptability, which were better in group 2 sausages, although the cross-section colour was slightly better in group 1 kulen, which had more cayenne pepper and category 1 pork meat. The odour and taste, as well as other sensory properties of fermented products were influenced by the quality of raw material, ingredients, the metabolic activity of the microbiota present, the physicochemical changes due the drying and ripening processes, and enzymatic degradation of proteins and fats (Virgili et al., 1999; Vukovic et al., 2009). Sausages with a smaller content of fatty tissue are less juicy, have a more solid consistency, and the surface is uneven and wrinkled (Mendoza et al., 2001).

\section{Chemical characteristics}

The chemical composition of the two different groups of kulen sausages are shown in Table 3. The results obtained show that group 1 kulen had a higher protein content $(24.52 \%)$ than sausages in group 2 , which had $23.00 \%$ meat protein, while the content of collagen in meat protein in group 2 kulen was $9.16 \%$. This was more collagen in meat protein than the group 1 kulen contained $(7.02 \%$ of collagen in meat protein). The final protein contents in these sausages were similar to the majority of reported protein

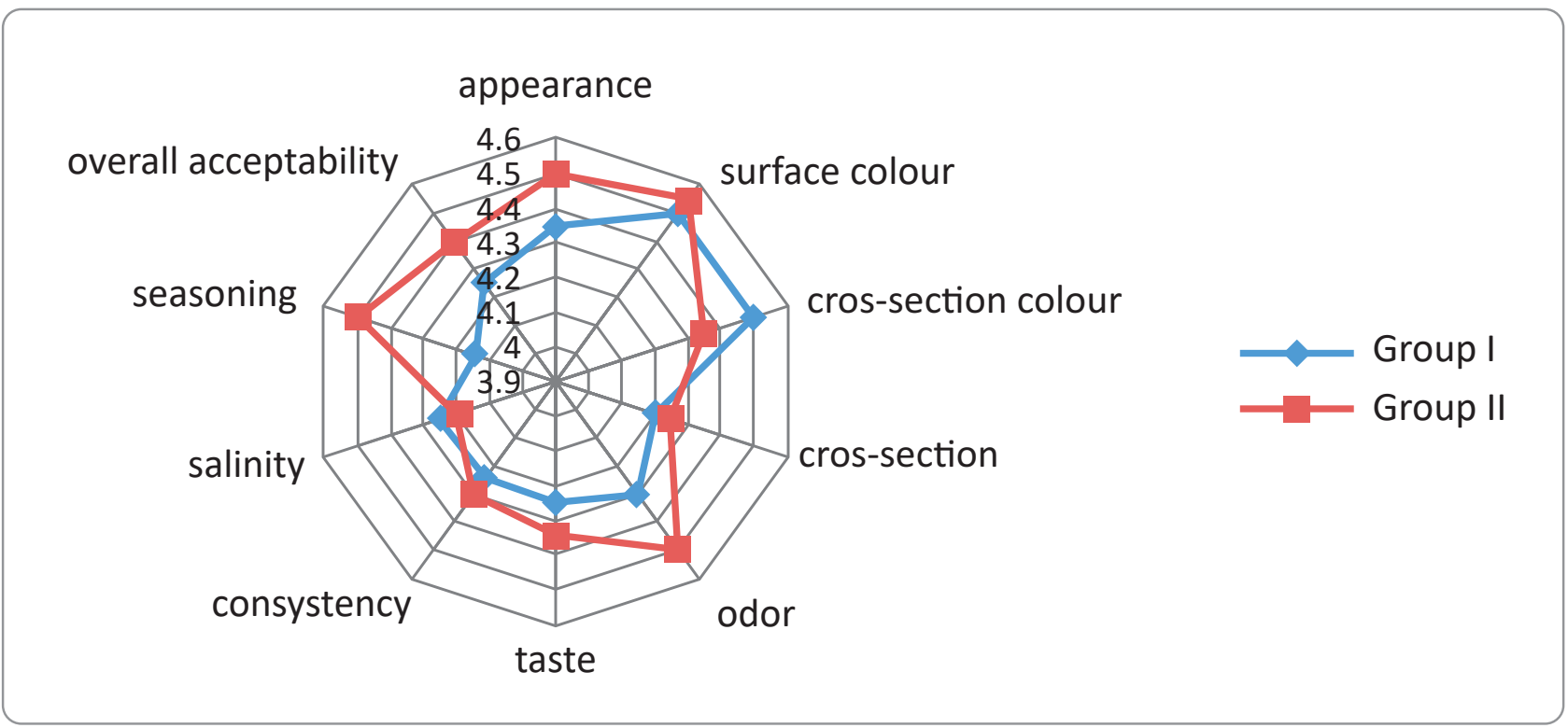

Figure 1. Sensory properties of kulen fermented sausage (group 1 and group 2) (Significant differences were found between taste, odour and overall acceptability between the two groups of sausages $(p<0.05)$ ) 
Table 3. Chemical composition of kulen fermented sausages (mean \pm standard deviation)

\begin{tabular}{lcc}
\hline Traits & Group 1 & Group 2 \\
\hline Protein (\%) & $24.52 \pm 1.02^{\mathrm{a}}$ & $23.00 \pm 1.00^{\mathrm{a}}$ \\
Collagen (\%) & $7.02 \pm 0.90$ & $9.16 \pm 0.90$ \\
Ash (\%) & $3.81 \pm 0.05$ & $4.32 \pm 0.07$ \\
Water (\%) & $31.47 \pm 2.40$ & $23.93 \pm 1.90$ \\
Fat (\%) & $36.99 \pm 3.10^{\mathrm{a}}$ & $39.59 \pm 3.90^{\mathrm{a}}$ \\
$\mathrm{NaCl}(\%)$ & $2.81 \pm 0.01^{\mathrm{a}}$ & $3.37 \pm 0.01^{\mathrm{a}}$ \\
$\mathrm{pH}$ & $5.31 \pm 0.90$ & $5.33 \pm 0.80$ \\
$\mathrm{a}_{\mathrm{W}}$ & $0.841 \pm 0.001$ & $0.856 \pm 0.001$ \\
\hline
\end{tabular}

Legend: The same letters in a row show statistically significant differences between the two groups of sausages, $\mathrm{p}<0.05$

contents in a range of different fermented sausages (Comi et al, 2005; Saldago et al., 2005). Fermented sausages are meat products with high fat content, approximately about $35 \%$, but this value can rise to about 45-60\%. (Gomez and Lorenzo, 2013). Some sensory properties, such as hardness, juiciness and flavour depend on fat content, and the high fat content $(40-50 \%)$ is essential for these sensory properties (Wirth, 1988). The naturally fermented dry sausages from the Mediterranean region are generally characterized by low acidity with a final $\mathrm{pH}$ ranging from 5.2 to 6.4 (Comi et al, 2005; Fista et al., 2004), which matches our results. According to Heinze and Hautzinger (2007) the water activity $\left(\mathrm{a}_{\mathrm{w}}\right)$ of fermented dry sausage is in the range from 0.70 to 0.96 . In our study, $a_{w}$ was 0.841 and 0.856 for group 1 and group 2 kulen, respectively. Moisture contents in our sausages were less than $35 \%$. The two main factors contributing to the safety and stability of these products are low $\mathrm{pH}$ and reduced $\mathrm{a}_{\mathrm{w}}$. In general, dry sausages have a final $\mathrm{pH}$ of $5.0-5.3$, the moisture loss is between $25-50 \%$ and the final $\%$ moisture is around $<35 \%$ with $\mathrm{a}_{\mathrm{w}}$ ranging from $<0.85$ to 0.91 . Significant differences were found in fat and protein contents between the two groups of kulen sausages $(p<0.05)$. Table 4 and 5 show the correlations between chemical composition and sensory properties of the two groups of kulen sausages. We found very good and positive correlation between protein content and overall acceptability (according to Colton, 1974). Similarly, very good and positive correlation between was found between fat and taste.

Table 4. Correlations among some parameters for the group 1 kulen fermented sausages (Pearson correlation coefficients)

\begin{tabular}{lcccc}
\hline Parameter & Overall acceptability & Consistency & Taste & Odour \\
\hline Protein & 0.962 & 0.241 & 0.735 & 0.455 \\
Collagen & 0.433 & 0.251 & 0.408 & 0.216 \\
Fat & 0.407 & 0.726 & 0.805 & 0.637 \\
\hline
\end{tabular}

Table 5. Correlations among some of the parameters for the group 2 kulen fermented sausages (Pearson correlation coefficients)

\begin{tabular}{lcccc}
\hline Parameter & Overall acceptability & Consistency & Taste & Odour \\
\hline Protein & 0.861 & 0.240 & 0.635 & 0.450 \\
Collagen & 0.420 & 0.230 & 0.390 & 0.200 \\
Fat & 0.400 & 0.710 & 0.800 & 0.620 \\
\hline
\end{tabular}




\section{Conclusion}

The results of this study shows that different quantities and qualities of pork meat and different amounts of sweet and cayenne pepper can affect the sensory properties of kulen fermented sausages. In this case, the odour, taste, cross-section colour and overall acceptability were especially affected. However, the differences in sausage composition resulted in dissimilar protein, collagen in meat protein and fat contents in the final products. Therefore, the raw materials and the other ingredients used in the technological production of this fermented sausage can affect the quality of the final kulen sausage product.

\title{
Ocena senzorskih i hemijskih parametara fermentisanih kobasica
}

\author{
Ivana Branković Lazić, Jelena Jovanović, Stefan Simunović, Mladen Rašeta, Dejana Trbović, Tatjana Baltić, \\ Jelena Ćirić
}

A p s tr a kt: Fermentisane kobasice su visokokvalitetni proizvodi industrije mesa i kao takve su veoma cenjene i tražene. Ove vrste kobasica u današnje vreme se najviše vezuje za industrijski način proizvodnje, što znači da kvalitet proizvoda nije standarizovan, ali je prihvatljiv za većinu stanovništva, jer ga karakteriše privlačan spoljašnji izgled i prijatna aroma. Cilj ovog rada jeste da se ukaže na postojanje razlika u senzorskim $i$ hemijskim parametrima, između dve grupe fermentisanih kobasica tipa kulena za čiju proizvodnju su korišćene dve recapture koje su se razlikovale prema upotrebljenoj kategoriji mesa svinja, kao i količini slatke i ljute paprike. Dobijeni rezultati su ukazali na postojanje razlika u senzorskim osobinama proizvoda, mirisu, ukusu i ukupnoj prihvatljivosti proizvoda, dok su hemijskim ispitivanjima utvrđene razlike u sadržaju proteina mesa, koji se kretao od $23.00 \%$ (grupa 2) do 24.52\% (grupa 1) i sadržaju kolagena u proteinima mesa $7.02 \%$ (grupa 1) i 9.16\% (grupa 2). Sve ukazuje da izbor sirovine i upotrebljenih sastojaka može imati uticaja na senzorska i hemijska svojstva ovakvog tipa proizvoda.

Ključne reči: fermentisane kobasice, senzorska analiza, hemijska analiza.

Disclosure statement: No potential conflict of interest was reported by authors.

\section{References}

Babic, Lj. \& Babic, M. (2000). Susenje i skladistenje. Poljoprivredni fakultet, Novi Sad.

Brankovic Lazic, I., Lilic, S., Jovanovic, J., Raseta, M., Mrdovic, B., Trbovic, D. \& Nastasijevic, I. (2019). Assessment of sensory and chemical parameters of tea sausage. Meat Con 2019. IOP Conference Series: Earth and Environmental Science. https://iopscience.iop.org/ article/10.1088/1755-1315/333/1/012048

Comi, G., Urso, R., Iacumin, L., Rantsiou, K., Cattaneo, P., Cantoni, C. \& Cocolin, L. (2005). Characterisation of naturally fermented sausages produced in North East of Italy. Meat Science 69, 381-392.

Colton, T. (1974). Regression and correlation. Statistics in medicine, 189, 218.

FAO. (2013). Small-scale sausage production .

Fista, G. A., Bloukas, J. G. \& Siomos, A. S. (2004). Effect of leek and onion on processing and quality characteristics of Greek traditional sausages. Meat Science 68(2), 163-172.

Gómez, M. \& Lorenzo, J. M. (2013). Effect of fat level on physicochemical, volatile compounds and sensory characteristics of dry-ripened "chorizo" from Celta pig breed. Meat Science 95, 658-666.
Heinz, G. \& Hautzinger, P. (2007). Meat Processing Technology for Small to Medium Scale Producers. Food and Agriculture Organization of the United Nations Regional office for Asia and Pacific, RAP Publication, Bangkok.

Mendoza, E., Garcia, M. L., Casas, C. \& Selgas, M. D. (2001). Inulin as fat substitute in low fat, dry fermented sausages. Meat Science 57, 387-393.

Petäjä-Kanninen, E., \& Puolanne, E. (2007). Principles of Meat Fermentation. Handbook of Fermented Meat and Poultry 555, 31-36.

Petrohilou, I. \& Rantsios, A. (2005). Tehnologija Mesa 3(4), $138-142$.

Saldago, A., Fontan, M. C. G., Franco, I., Lopez, M. and Carballo, J. 2005. Food Chemistry 92, 413-424.

Savic, I. V. (1985). Small-scale sausage production http://www. fao.org/docrep/003/ x6556e/X6556E00.htm

Serbia. (2015, 2017). Regulation on the quality of ground meat, meat preparations and meat products Official Gazette of the Republic of Serbia 94 (104) 19.

SRPS ISO/IEC 17025:2005. General requirements for the competence of testing and calibration laboratories. 
SRPS ISO (1998a). 1442:1998. Meat and meat products — Determination of moisture content.

SRPS ISO (1998b). 1444:1998. Meat and meat products - Determination of free fat content.

SRPS ISO (1999). 1841-1:1999c. Meat and meat products — Determination of chloride content — Part 1: Volhard method.

SRPS ISO (2001a). 3972:2001. Sensory analysis - Methodology - Method of investigating sensitivity of taste.

SRPS ISO (2001b). 6658:2001. Sensory analysis - Methodology - General guidance.

SRPS ISO (2002a). 3496:2002. Meat and meat products - Determination of hydroxyproline content.

SRPS ISO (2002b). 5496:2002. Sensory analysis - Methodology - Initiation and training of assessors in the detection and recognition of odours.

SRPS ISO (2004). 2917:2004. Meat and meat products Measurement of $\mathrm{pH}$ value.

Paper received: 15.11.2019.

Paper corrected: 9.12.2019.

Paper accepted: 9.12.2019.
Veskovic Moracanin, S., Karan, D., Okanovic, Dj., Jokanovic, M., Dzinic, N., Parunovic, N. \& Trbovic, D. (2011). Colour and texture properties of traditionally fermented "Sremska" sausage. Tehnologija Mesa 52 (2), 245-251.

Virgili, R., Parolai, G., Soresi, B. C. \& Schivazappa, C. (1999). Free ammo acids and dipeptides in dry-cured hams. Journal of Muscle Foods 10, 119-130.

Vukovic, I. (2012). Osnove tehnologije mesa, Cetvrto izdanje.

Vukovic, I., Saicic, S., Vasilev, D., Tubic, M., Vasiljevic, N. \& Milanovic-Stevanovic, M. (2009). Neki parametri kvaliteta nutritivna vrednost funkcionalnih fermentisnih kobasica. Tehnologija Mesa 50 (1-2), 68-74.

Wirth, F. (1988). Technologies for making fat-reduced meat products. Fleischwirtschaft 68, 1153-1156.

Zukál, E. \& Incze, K. (2010). Drying. Handbook of meat processing 566, 219-229. 